\title{
The Effects of Governance in the Independent Kosovo
}

\author{
Adem Shala \\ PhD Candidate at the European University in Tirane \\ Department of Juridical Sciences: Doctoral Research in Governing Processes \\ Email: shala.ad@live.com
}

\section{Doi:10.5901/mjss.2014.v5n16p42}

\begin{abstract}
Global effects, depending on regions and countries, have taken specific characteristics. Specific effects were in the transition countries. The crisis and reforms in these countries and societies were a result of local efforts to change the conditions of all scopes. In order to achieve these goals, transition countries, needed support from developed countries and global organizations. Global effects were not enough, were inefficient, delayed, unclear, uncoordinated, unreformed, and inadequate among others. Furthermore, social, economic and native political initiatives were unable to promote reforms without foreign help. In the case of Kosova, the global effects were even more specific as a result of the large collection of problems over longer periods of time, and the politics of the surrounding countries, especially the dominating Serbian politics. The activity and the determination of the Kosovar society to overcome the situation compelled the International Community towards establishing attitudes, making decisions and acting, among others, in the case of Kosova. Kosova, as a country that belongs to all communities and citizens, is a specific case. The governing processes and institutions are directly influenced by the International Community and global effects. This Kosova specific governing process is a compound of two processes, specific kosovar circumstances and global effects in the region. A special approach should be applied when global effects are evaluated and analyzed in the case of Kosovo, of special interest the practical and theoretical activity, for understanding problems, circumstances, and causes as well as the way towards surpassing obstacles and the advancement of positive processes in governing, institutions and development. Effective governance in Kosovo should aim to create the enabling environment prerequisites for the development and integration process. This is the key role, function and essential obligation of this process. Gonverning institutions in Kosovo should be an interacting and guarantee factor in regards to the development and integration processes. This role and function, in line with a democratic orientation, of the Kosova leadrship is beeing demanded by the society and the Internatnional community.
\end{abstract}

Keywords: Kosova, Global Effects, Governing, International community, Development

\section{Introduction}

\subsection{Aims and research questions}

Kosovar institutional and governing quality represents an essential factor in the development and integration process. After the independence of Kosovo in 2008, the preconditions were created for governance and institutional organization based on constitutional and legal definitions in accordance with democratic standards and international law. Successful developments have occurred on governance and the legal and institutional environments of the regional security however, there is still a need for more efficient, higher quality and more effective legal and political order. Political entities and the society through the governmental process and other processes are required to change and overcome these circumstances in favor of creating the preconditions for economic growth and development. These obligations will be achieved based on the outcomes of major political institutions: legislative, executive, judicial, administrative and the relationship between thr four of them through the engagement of political parties in governance, implementation the constitution. Through political pluralism, democratic elections create legitimacy for the government and initiate positive change.

Processes, decisions, actions and neglect of the international community had and continue to have a special role in the institutional developments and political processes of governance in and around Kosovo. However, this is dependent on the social, cultural and political forces of Kosovo. Kosovar politicians and citizens should understand more seriously that now the quality of the governance process is essential for development and integration. Without the rule of political order and the rule of law, there is no certainty for investment, economic activity or integration. Therefore, the quality of governance, the rule of law, democracy, respect for human rights and respect for minority rights, bring peace in 
Kosovo and the region. They provide safe conditions for investment, regional cooperation, integration and ultimately development.

The purpose and contribution of this paper lies in finding the answers to the questions: What are the causes, consequences, challenges, activities and effects of governance in the years 2008-2013? Which are the challenges which kosovar insitutions and government face after independence and in the future? How to achieve qualitative effects of governance? What are the negative trends in governance and institutions, and how to overcome them?

\subsection{Model and methods}

This study used multiple viewpoints on appropriate methods for understanding the causes, consequences, and variable correlations and effects. This study focused on researching specific facts related to Kosovo and in understanding the interpretation of local and international legal acts that relate to and interact with the processes on the Kosovar governance while employing models and strategies of research on comparisons, evaluations, observation ethnography, grounded theory, and evaluating the facts and processes related to the topic on the above mentioned area. This study used the experimental model represented through active and passive observations which is a time limited study of concrete phenomena. Furthermore, the study conducted analysis of monitoring reports of international institutions on governance and Kosovo institutions, analysis of reports of the institutions themselves and ports of civil society organizations, and independent monitoring agencies of the government of Kosovo. Comparisons were drawn with modern views of theories on the conditions and objectives of democratic governance.

\section{Effects of Governance in an Independent Kosovo}

\subsection{Institutional and juridical consolidation}

Legal and institutional consolidation in governance in the independent Kosovo, is based in The Ahtisaari Plan (Comprehensive Proposal for the Kosovo Status Settlement, March 2007) and international supervision of its implementation. Article 1.3 of Ahtisaari 's Plan states: "Kosovo shall adopt a Constitution. The Constitution of Kosovo shall prescribe and guarantee the legal and institutional mechanisms necessary to ensure that: Kosovo is governed by the highest democratic standards, and to promote the peaceful and prosperous existence of all its inhabitants. The Constitution shall include, but not be limited to the principles and provisions contained in Annex I of this Settlement". This plan provides for the regulation of political and legal system in general, and some areas are defined in detail. In Article 1.1 (General Principles) it stipulates that: "Kosovo shall be a multi-ethnic society, which shall govern itself democratically, and with full respect for the rule of law, through its legislative, executive, and judicial institutions". The Ahtisaari Plan defines Kosovo as a multiethnic democratic society, non-religious, with Albanian and Serbian as official languages, with a market economy and open and free competition. It provides key elements for minority rights and a strong form of decentralized local governance at the municipal and central level, in particular for the northern Serb minority community.

Positive ratings come from all relevant international institutions regarding the implementation of the Ahtisaari Plan. An analysis conducted by Gerard.M.Galluci in 2011 in the context of affiliation on Serb northern municipalities states that the Ahtisaari Plan provides a framework for a functioning multiethnic democracy, although all minorities in Kosovo constitute about $8 \%$ of the population. The aim was for the Serbian minority to be provided with a special status in order to integrate and eliminate destructive policies of Serbia towards Kosovo. In the case of Kosovo there were no interethnic conflicts, but it was the exploitation of the Serb minority by dominant Serbian policies and international toleration. Serbia's destructive policies aim was the prevention of the creation of institutions and establishment of the governance of Kosovo as an independent state, not for the interests and rights of the Serb minority. In order to limit the obstacles of Serbia solutions included in Ahtisaari plan became eligible for the kosovars, given that Kosovo is not a pronounced multiethnic society. But the real solution of this problem is done by preventing the intrusive policies of Serbia and its allies against the independence of Kosovo because the effects of these policies are reflected in the governance.

With the establishment of international guidance the Assembly proclaimed the Declaration of Independence on $17^{\text {th }}$ of February 2008. International recognition followed, with a significant number of countries with a global impact accepting it. Kosovo's constitution (2008) determined the character, functions and organization of the institutions. All the definitions and governing authority of institutional powers were consolidated in compliance with the requirements of the Ahtisaari Plan, by guaranteeing all ethnic groups, civil rights, especially in regards to the Serb minority in Kosovo. The Constitution defined the political and legal system: parliamentary republic with a system of governance similar to that of Western democracies and transition countries. A unique state with a decentralized local municipal government. The constitutional 
politics fits the level and goals of the democratic society of Kosovo. The constitution of Kosovo represents the basic solutions to government and institutional processes according to democratic standards. The Constitution, as the supreme legal act of the Republic of Kosovo in Chapter I on Basic Provisions, Article 16.2, Supremacy of the Constitution states: "The Power to Govern stems from the Constitution". Chapter I, Article 2.1 on Sovereignty defines "The sovereignty of the Republic of Kosovo stems from the people, belongs to the people and is exercised in compliance with the Constitution through elected representatives, referendum and other forms in compliance with the provisions of this Constitution". By expressing the supremacy of this act and its constitutionality in the governing process, Chapter I, Article 16.2 defines: "The Constitution is the highest legal act of the Republic of Kosovo. Laws and other legal acts shall be in accordance with this Constitution". In Article 4.1 [Form of Government and Separation of Power]: "Kosovo is a democratic Republic based on the principle of separation of powers and the checks and balances among them as provided in this Constitution".

In accordance with the Constitution, laws, procedures and other relevant regulations, all institutions were constituted according to powers and responsibilities. International Court of Justice in The Hague UN on the 22 ${ }^{\text {nd }}$ of July 2010, published a positive advisory opinion concerning the legality of Kosovo's declaration of independence in 2008, noting that there is no contradiction on United Nations Resolution 1244, adopted by the Security Council. Among the major successes is the end of international supervision of independence (September 2012), which marked the completion of the implementation of the criteria required by the Martti Ahtisaari package. So, with this the constitutional preconditions, legal and organizational functioning, the establishment of institutions and governance of the Republic of Kosovo were completed. However, this governance did not reach the north.

\subsection{Conditions and the effects of governance}

The governance process has faced adverse conditions: a) the absence of a plural democratic tradition; b) low level of economic development hence business environment unfit; c) delay in transition reforms; d) external obstacles such as the political business culture of the past; d) the concentration of power on the existential resource sectors; e) negative phenomenon in institutions; lack of genuine opposition etc. All these circumstances are affecting directly the characteristics of governance and institutional efficiency.

\subsubsection{Tradition and socio-cultural circumstances}

The socialist system, national oppression of Albanians in Yugoslavia, suspension of autonomy in 1989, violations of the population and the democratic processes in Kosovo had direct consequences on the lack of democratic governing tradition. Even during the international administration as a result of the lack of status, Kosovo's political parties had very little competences in the process joint governance. Democratic governance requires as a prerequisite a preexisting democratic political and cultural tradition in governance. In Kosovo this tradition lacked as a result of past governance. Cultural theories speak of the cultural tradition of religious affiliations of the population in the form and effects of the government. In Kosovo, we have a culture with a large secular scale, and this is impacting positively on democratic governance, in comparison to other countries loaded with fundamental religions. In Kosovo, we have separation of state from religion and public life, we have no impact of religious fundamentalism in the politics and state. The cultural values are not at the right level, which are an essential prerequisite for the quality of democratic governance, such as voter - elite consensus, altruistic values towards the community, positive traditions towards institutions, traditions of respect for human rights and the law, education and understanding about the costs and benefits of democratic government, knowing the long-term costs of unfit governance, optimism, attitude toward equality, against corruption, against that past attitudes, interpersonal relationships, establishing democracy etc. The following are still not at the right level: respect for individual freedom, the idea of equality, trust in the power of speech, the importance of persuasion, rhetoric, and constructive debate and compromise. We lack the tradition of respecting individual rights, we have primarily put the family and clan before the individual, prone to violence, poor separation of powers, the tendency for government undemocratic concentration of power over the economy and income as a result underdevelopment and the lack of competition in the private sector etc. Therefore, to achieve appropriate governance effects, we have to advance urgently these essential values through multiple ways. In this regard goes the doctrine of human development. Institutionalized cultural and human values which are legally protected are required.

According to democratic theories (Inglehart \& Wellzel, 2005) it is required that at least $45 \%$ of citizens are determined towards democratic governance. Therefore, the problem lies in the Kosovo governance, because, as a result of the concentration of power, unemployment, poverty, political values and culture, media etc. Voters run after parties and 
leaders benefits in the public sector, not for genuine democratic governance. Of importance are also the following: work habit, approach towards business and property, sense of responsibility, displaying self values, but also the socioeconomic level and economic processes which create new motif and cultural values of governing.

\subsubsection{Economic Development Level}

Favorable environment for democratic governance and its goal is sustainable economic development. Martin Lipset emphasized that: "The richer a country is, the greater are the opportunities to save democracy" (1959). This applies also to the Republic of Kosovo in order to see results and effects on democratic governance it is a necessity for sustainable economic development and transformation of this increase in the development of other areas in Kosovo. The lack of private economic development is costing the government in Kosovo, because there is no distraction of power over existential resources. Without the private economic development sphere there is no democratic governance, no diversion of power, and no advanced civil society. However, without effective governance, rule of law and order, security, appropriate economic policies, administration, quality, quality public services, integration etc. which should be provided by good governance, there will be neither economic development nor a civil society. There is a mutual conditional correlation and interaction in order to overcome the situation. This challenge can and should be managed by adding political legitimacy to its effectiveness; by complementing government system functions in the rule of law; by protecting public interests and the interests of the majority of the population; structural conflict resolution; by politically integrating the middle and lower classes; by paying attention to distribution etc. The aim is to create preconditions for liberalization and a market economy; clear policies towards the successful development of medium and long term projects. All fields must be in favor of the development and future perspective because economic development reflects the opportunity for democratic governance and its sustainability. Nevertheless all this depends on strengthening the rule of law and the establishment of security, infrastructural preconditions and public services. Clear development policies and the withdrawal of political and group power towards the economy is required; liberalization and intense economic cooperation, competition in the regional and global levels; political security and social security, and social security during the transformation. Specifically, preparation for integrating into the EU economy and the separation of the economy from the direct management of the state and government. Fukuyama, F. (2010; 142) seeks long-term economic liberalization on one hand, but requires strengthening institutions and other areas of safety and security on the other. In the absence of understanding, approach and implementation in some developing and transition countries he states that: "economic liberalization reforms failed to achieve its objectives in many countries. Indeed in some countries the lack of proper institutional framework left them worse after liberalization than they would be without implementing it at all. The problem lies in the basic conceptual failure to separate the different dimensions of the state and to understand how they relate to economic development". This is happening in politics, government and the Kosovo institutions, ranging from institutional framework, lack of economic liberalization, lack of strengthening key institutions and lack of rule of law as a primary necessity . In the absence of sincere intentions of the political elite and long-term development and in the failure to understanding the need to separation the roles of institutions in relation to the economy. Therefore, the lack of understanding towards how to influence economic development through strengthening of key political institutions and economic liberalization simultaneously. Consequently, there is a demand for the construction of the economy according to an open economy towards regional, European and world market, with an appropriate enforcement of regulatory policy, security and rule of law in other areas, and understanding that these non-economic functions of governance although seem indirect, are essential for economic development.

Stimulating economic and political cooperation promotes joint investments with foreign partners. The development of human capital in accordance with technological trends and market and competition laws in the regional and global level, for the Kosovo government should be the main priority noted the United Nations Development Programme (2009; 2010; 2011). The effective management of human resources and attractions of the capital in strategic investments and economic liberalization for Kosovo, which will bring rapid and sustainable development. WB, IMF, UNDP, CBK, (20082013). The statistics agency and local institutions, provide disturbing figures on poverty and unemployment in Kosovo. Kosovo's economy has a positive growth rate, but this is insufficient for a sustainable development and reduction of the trade deficit, poverty and unemployment. Privatization and many other services in Kosovo are associated with groups and corrupt power, as a result of lack of rule of law and order. The role and function of Kosovar governance is to create an environment for economic growth and development in all areas which benefits the wellbeing and the human development of every citizen in Kosovo.

However according to the findings of CBK (December, 2012) the Republic of Kosovo has managed to maintain macroeconomic stability. Economic growth continues to be positive, keeping the level of public debt reasonable. 
Pronounced dominance of the trade deficit, higher import rates in comparison to local manufacturing abilities of those products, very low export with export covering import only about $16 \%$, are indicative of ineffective policies. Commercial banks provide inadequate loans, there is inflation, low investment and weak suction of local and foreign investments (CBK, 2010). Opportunities and some potential development factors exist: human capital, natural resources unused, and market which in a consistent macro-economic policy and rule of law, will activate these Kosovar economic potentials.

\subsubsection{Deconcentration of power}

Democratic governance in Kosovo seeks deconcentration of power resources in the society and economy: ownership, capital, knowledge, information, attraction of the partisan power from public services, efficient administration, freedom of movement and conditions for business activity. Without economic development of the private sphere in Kosovo, there can be no deconcentration of power, and no genuine civil society. All current employment and suvival opportunities are dependent on the public sphere, which are lead by party elites and groups of interest and pressure, created by the negative phenomena in institutions and governance which have become abusers of institutions. Kosovo government and institutions should protect the citizen from the pressure of pressure groups, corrupt groups in power and other groups associated with them. These groups and extreme concentration of power over existential resources are obstacles for democratic governance and are increasing uncertainties for investment and the genuine development of the private sphere of integration and competition. Voters in this situation of poverty, unemployment etc. are more easily manipulated by political demagogies and are running after power concentrators and occupants of the governancve and institutions believing in empty promises.

On the prerequisites of democratic governance Vanhanen (2003) stated that "the concentration of power resources leads to autocracy, and deconcentration of power sources in most cases in a democracy". In the deconcentration of power, many forms of decentralization play a role along with the development of the private sphere. Seymour Martin Lipset in the work Political Man (1960) required resource allocation of power resources in society and the economy in order for the power not to own these resources. In his view Lipset also introduces other indicators of resource allocation: sources of knowledge, economy, the state of the property, agricultural property, information etc. in relation to the government. In Kosovo the analyses and indicators of local and international monitors show multiple instances of institutional group power over economic public resources, knowledge, information etc. This reduction, and deconcentration of power over the economy, does not mean the destruction of the state and institutions, on the contrary, it requires strengthening the effectiveness and of institutions in the areas of rule of law according to the constitution. Without this there are no appropriate institutions, or economic development in Kosovo. This requires the international community and the global economic integration processes. This is the message Fukuyama $(2010 ; 175)$ passes on, A vital problem faced by poor countries that blocks their opportunities for economic development, is the inadequate level of institutional development. They do not need extended states, but need strong states and effective within the limited scope of essential state functions. Most of these problems were faced during the institutional development and governance in Kosovo.

\subsubsection{Regional and international circumstances}

Democratic governance is easier for countries that lie among the developed democratic countries. Unfortunately, Kosova did not have this position with regards to neighboring countries. Another important positive factor for the democratic governance in Kosovo are the integration processes of the region in the EU and its position in the market and golobal processes in the region. Changes after the 90s, the European integration processes, global processes in many areas, geographical position, exposing position of the global market, regional investments, etc. are a positive and influential force for concrete processes in Kosovo, of course, besides the engagement of the Kosovar factor. Negative impacts from Serbia and rivalities of contries with an impact countries reflected directly in the governing effects and the institutionalization in Kosovo. And all these factors created obstacles and delays in government reforms, integration and hence in the democratic consolidation in Kosovo. But global integration processes and activities of international organizations are affecting Kosovo, in order to incorporate conventions and practices of democratic governance which is useful in the constitutional order in respecting human rights, minority rights, rule of law and order. Therefore, the need for political, institutional, economic, legal and cultural reforms is evident. 


\subsubsection{Constitutional politics}

An essential factor is considered to be the appropriate adjustment, clear and deliberate constitutional policies for effective governance, with predictions: the parliamentary system and balancing powers; proportional electoral system; guarantee of human rights under international conventions and standards (see: Chapter II Fundamental Rights and Freedoms); the rights of minority communities (see Chapter III Rights of Communities and theire Members); decentralization through local governance at the municipal level (Chapter X Local Government and Territorial Organization); After the independence in 2008, concrete successes have been achieved in the legal and institutional consolidation of governance, but an effective and quality implementation of political and legal order; rule of law, is requried by fighting negative phenomena in institutions in order to prevent the alienation of the policy goals in regards to constitutional governance.

Legal obligations, constitutional law, separation of powers etc. limit the power in relation to political rights and freedoms and social rights of individuals. Rule of Law according to Wolfganag Merkel sets the following: political institutional determinants and "partial regimes, encompassing and free elections, the political rights to participate, civil liberties, ensuring institutional control and security powers de jure and de facto power of the elected representatives" stresses Merkel (2010). However, without a political culture, without economic opportunities, deconcentration of power, favorable international position and integration it is difficult to achieve effective democratic governance. The model of limiting government control of society, the opposition, the right, the balance of powers, decentralization, international law, distribution of resources, values, democratic attitudes and behaviors, international atmosphere and global processes however, are providing an environment relatively suitable for institutional processes and democratic governance in Kosovo.

\subsection{Negative phenomena in institutions}

In Kosovo government, occupation occurred by party leaderships and the penetration of corrupt groups in institutions and not fighting negative phenomena in institutions for a long time. These circumstance causes, affected the quality of institutional functions at the level of implementation of roles and powers of the parliament itself as the basic institution of parliamentary democracy, and consequently other institutions. Non-compliance to law, the lack of autonomy of powers and mutual lack of control, especially of parliament over the executive. Ineffective judiciary towards high-level corrupt individuals, lack of proper functioning of the electoral process, caracteristics of political parties and of their leadership have brought consequences on the growth of corruption and organized crime, as well as failing to fight it.

Negative phenomena in institutions are damaging the state budget, economy and society: by preventing and distorting public investments and by creating uncertainty for potential internal and external investors. These phenomena are directly impacting on economic underdevelopment, insecurity, the quality of public and administrative services, and the delayed integration. Therefore, specific measures and governanment reforms to overcome the situation are mandatory. The World Bank Director for Southeast Europe, Jane Armitage, in an interview, (November, 2012) by demanding reforms in these spheres in Kosovo states that "much work has to be done, fight corruption, improving the judiciary; all these are part of the business environment. When making business and business indicators, investors look at all these indicators". This situation continues because the Judiciary is still inefficient, not independent enough and connected to negative phenomena in government, while it is also under the pressure groups interest and pressure groups in higher institutions.

Functioning of the judiciary is essential to the rule of law, but is not yet independent and effective. In legal and constitutional terms it seems independent, but the actual aspect is rather differet. Kosovo in the opinions of citizens and monitoring organizations, whether international or local, qualifies as a state with a high level of corruption in: public enterprises, in the procurement process and in government spending. Employment in administration and other public spheres are due to nepotism and partisanship without regard towards professional and ethical qualities. There is a politicized public administration on party grounds and still unreformed enough.

Real competition of parties lacks as a result of negative phenomena induced in the party leadership itself, and through them in institutions. Races between them are not made for governing and program alternatives, but for embezzlement, misuse and group privileges. Therefore, debates between them are harsh, abusive, destructive and labeling. In all monitoring reports of local and international organizations and investigative, among others, indicate that the highest political elites are corrupt through manipulating the privatization process, and tenderes' misuse and in the procurement process, the costs of unchecked government budget from misuse donor funds, corrupt public-private partenerships, nepotism etc. These groups apart from pressures and corruption, informality, organized crime and smuggling are hindering democratization and constitutional and legal legal functioning of institutions. They manipulate 
and distort the electoral process and the manipulation of public opinion through the dependent media, blackmail, demagoguery, etc. These groups bring their loyal individuals in major institutions and independent agencies. These phenomena and their holders are hampering democratic governance and consequently, are hampering economic growth, development and integration of other areas. Corruption in Kosovo is part of the system. The holders of power and institutions are involved in such phenomena. According to Global Corruption Barometer (July 2013) political parties have been identified as the area most affected by corruption in Kosovo, and government efforts to combat it are extremely inefficient. Kosovo in 2012 ranked 105th on the list of most corrupt countries (July, 2013).

Combating the aboved mentioned negative phenomena can be achieved by coordinating the activity of: citizens, opposition political parties and new leadership, with the clear support of the positive international factor. Unity and coordination of these factors can produce results by consolidating the integrity of institutions and governance process. Starting from transparency, changing the structure of consciousness and voter values, consolidating and respecting democratic principles of the electoral process and the legitimacy of institutions. Returning thus the efficiency and integrity of institutions. Empowerment of civil society, independent media , critic and analysis. Effective international support through pressures, but also by speeding up the integration is more than necessary. Sustainable economic development represents a necessity for democracy, but it can not be achieved without accountable and effective governance and institutions, it cannot be achieved without preliminary effects of security, order and law and without supporting the integration.

Consolidation of the justice system with bold and independent staf in reagards to corrupt politics is a step forward, but it requires support of all institutions and citizens. The head of the European Commission Liaison Office in Kosovo (Khaldun, 2012) at the end of the term, in an interview emphasized that: "the fight against corruption, reform of the electoral system, reform of public administration, economic development of the country, are some of conditions that institutions must meet if they want to lead the country towards EU integration". He further notes in his interview "except institutions which have an obligation to fight corruption, one must remember that corruption is a problem of society and mentality". Therefore, there is a demand for changing multilateral commitments in the creation of values, knowledge and attitudes of voters; consolidation of opposition with leaders and staff with integrity; pressure and support from civil society; outside support through policy support and through the acceleration of integration. International support is effective and necessary because by identifying the causes and actors, informing, pressures and through the acceleration of the integration process, mobilizes citizens and the genuine opposition to act against negative phenomena. It enables the emergence of new opposition forces and their support.

\subsection{Integration processes}

There is no development in areas, integration with countries and regional and international organizations without the presence of capacity and quality of proper democratic governing institutions in Kosovo. In the case of Kosovo, it is imperative in all processes undergone and current ones. Therefore, the role and impact of governance quality is essential for developmental processes related to the national, regional and global integration processes. Kosovar society and politics should always be aware and prepared to create preconditions for positive and inevitable global processes to overcome the obstacles of negative hegemonic policies in the Balkans. These obstacles are multidimensional, and vocal against Kosovar integration. Therefore, Kosova by empowering institutions and governance quality, best exceeds these obstacles and together with positive international partners consolidates the integrity and international position of the state of Kosovo. Even the International Community in the basic requirements for integration is seeking quality and efficiency in governance, institutionalization and a democratic culture. Governance and democratic order in Kosovo reflects international peace and security in the region and beyond. Fukuyama points out that the lack of effective and lawful governance creates internal instability and has direct consequences in international stability (2010).

Although there were deficiencies, delays, contradictions, Kosovo has benefited greatly from the support given by the EU, U.S. and other countries and numerous international organizations. It has received considerable assistance, direct, institutional, legal, and financial governance. Conclusion of the Stabilisation and Association Agreement will contribute to the opening of Kosovar society. But no one should have illusions that Kosovo's path towards EU membership is easy. Requirements for membership are set by the European Council. Candidate countries, including Kosovo, should follow common values set out in the Treaty of Union and they are required to have achieved stability of institutions and democratic governance, as well as the existence of a competitive market economy, adopt and fully implement laws and standards of the EU, the so-called "acquis communautaire". This is a long process and a difficult one. While the EU will continue providing any kind of assistance. Results depend on Kosovo itself, from its leadership and citizens. For Kosovo it would be vital to be in the process of integration and integrated into the EU. This is the challenge 
of the Kosovar governing and institutional processes, together with the international community.

\subsection{Northern issue and relations with Serbia}

Legal solutions to the Ahtisaari Plan included in full in the Constitution and the political and functional legal system of Kosovo, as well as the successful integration of the Serb minority (except north), are undeniable arguments, and successful practices for solving problems of the north i.e. its integration. Even the international attitudes are clear that there is no change of borders on ethnic grounds. Therefore, Serbia's destructive role in the institutionalization of government in this part of Kosovo is being restricted. The Ahtisaari plan, Kosovo Constitution and the integration of the Serb minority in other parts of the Republic of Kosovo, are facts that indicate the guarantee and most advanced solutions in the region for the rights of the Serbian community in local and central government, the most significant democratic standards.

The diplomat Rohan (2012 ), as Ahtisaari's deputy in Vienna talks for setting the status of Kosovo, on the opening of negotiations for the normalization of relations between Kosovo and Serbia, in the context of north states that Ahtisaari Plan contains a substantial autonomy for the northern Kosovo Serbs. Therefore, he argues, any departure from this plan creates complications in the political and legal system of the Republic of Kosovo. This has been understood by all parties. Republic of Serbia also forced by domestic and integration needs, has begun to change the approach towards Kosovo and the north. Strengthening democratic institutions and the Kosovo government at all levels will affect the quality integration of this community and territory. The essence of the results of the negotiations for the north, in the spirit of the normalization of relations between Kosovo and Serbia under the mediation of the European Commission, Brussels (2013) is seen in the 15 point agreement, signed by prime ministers Thaci and Dacic. The key points of the Agreement are:

1. There will be an Association/Community of Serb-majority municipalities in Kosovo. Membership will be open to any other municipality provided the members are in agreement.

2. The Community/Association will be created by statute. Its dissolution shall only take place by a decision of the participating municipalities. Legal guarantees will be provided by applicable law and constitutional law (including the $2 / 3$ majority rule).

3. The structures of the Association/Community will be established on the same basis as the existing statute of the Association of Kosovo municipalities e.g. President, vice President, Assembly, Council.

4. In accordance with the competences given by the European Charter of Local Self Government and Kosovo law the participating municipalities shall be entitled to cooperate in exercising their powers through the Community/Association collectively. The Association/Community will have full overview of the areas of economic development, education, health, urban and rural planning.

5. The Association/Community will exercise other additional competences as may be delegated by the central authorities.

6. The Community/Association shall have a representative role to the central authorities and will have a seat in the communities' consultative council for this purpose. In the pursuit of this role a monitoring function is envisaged.

7. There shall be one police force in Kosovo called the Kosovo Police. All police in northern Kosovo shall be integrated in the Kosovo Police framework. Salaries will be only from the KP.

8. Members of other Serbian security structures will be offered a place in equivalent Kosovo structures.

This agreement clearly defines the form of the Association of Municipalities with Serb-majority in northern Kosovo, determining that "In accordance with the competences given by the European Charter of Local Self Government and Kosovo law the participating municipalities shall be entitled to cooperate in exercising their powers through the Community/Association collectively" (Point 4). "The Association/Community will exercise other additional competences as may be delegated by the central authorities" (Point 5). Local government as a form of decentralization represents one of the most essential and necessary principles of governance and democratic institutions. In Kosovo this is so in the municipal level and is the most advanced in the region.

Municipalities are enjoying a high degree of local self-government in the decision-making process of local authorities and are providing the necessary participation of all citizens. Kosovo's constitution in Chapter X on Local Government and Territorial Organization Article 123.4 [General Principles] defines "Local self-government is based upon the principles of good governance, transparency, efficiency and effectiveness in providing public services having due regard for the specific needs and interests of the Communities not in the majority and their members".

Municipalities have the right to inter-municipal and inter-border cooperation in areas of their own and enhanced competences. This is defined in Chapter X, Article 124 [Local Self-Government Organization and Operation] p. 3-7: 


\begin{abstract}
3. Municipalities have their own, extended and delegated competencies in accordance with the law. The state authority which delegates competencies shall cover the expenditures incurred for the exercise of delegation.

4. Municipalities have the right of inter-municipal cooperation and cross-border cooperation in accordance with the law.

5. Municipalities have the right to decide, collect and spend municipal revenues and receive appropriate funding from the central government in accordance with the law.

6. Municipalities are bound to respect the Constitution and laws and to apply court decisions.

7. The administrative review of acts of municipalities by the central authorities in the area of their own competencies shall be limited to ensuring compatibility with the Constitution of the Republic of Kosovo and the law.
\end{abstract}

Municipal governance represents advancement of democratic governance according to European standards and practices of local government. Chapter X on Local Government and Territorial Organization Article 123.3. states "The activity of local self-government bodies is based on this Constitution and the laws of the Republic of Kosovo and respects the European Charter of Local Self-Government. The Republic of Kosovo shall observe and implement the European Charter on Local Self Government to the same extent as that required of a signatory state". This is a requirement of all citizens and ethnic communities of the Republic of Kosovo, for development and prosperity for all.

To realize all these rights and purposes of local interest municipal competencies have also been regulated and functionalized: a. Local economic development; b.Urban and rural planing; c. Usage and land development; $d$. Implementation of building regulations and building control standards; e. Local environmental protection; $f$. Affiliation and maintenance of public services and utilities, including appropriate water supply, sewerage and drainage, waste management, local roads, local transport and local heating schemes. Central authorities in Kosovo delegate responsibility to the municipalities as municipal powers in the following matters: a.Territorial registry; b. civil registers; c. Voter registration; d. Registration and licensing of businesses; e. Distribution of social assistance payments (excluding pensions) and f. Protection of forests.

Municipal activities in areas of their own competencies are defined in ensuring compliance with the Constitution and the law in force. This is done by administrative review of municipal acts as foreseen in the Article 6-7 of Constitution's Chapter X:

6. Municipalities are bound to respect the Constitution and laws and to apply court decisions.

7. The administrative review of acts of municipalities by the central authorities in the area of their own competencies shall be limited to ensuring compatibility with the Constitution of the Republic of Kosovo and the law.

Municipal Local government is carrying out its functions successfully in all municipalities even in the Serb-majority ones in other parts of Kosovo, exept the north. Even the Association of Municipalities with Serb-majority in northern Kosovo, has no reason not to work as in other municipalities. Northern Municipal Association will be established in order to implement the constitutional and legal local government and in accordance with the competencies of central authority. Now the question is how to integrate this part as fast and as successfully for it to be institutionalized and governed in accordance with the Constitution; according to the quite advanced central government and local municipal government, according to the European Charter of Local Self-Government. The constitution and the legal and political order of Kosovo is unique with its advanced and functional local municipal governments and with substantive representation and participate in decision-making of minority communities in the central level. Therefore, there is no reason for any form of destructive presence that would ultimately undermine the multi-ethnicity and the democratic determination of kosovar governance.

\title{
3. Conclusion
}

After the declaration of independence (2008) until 2014, the legal form (Constitution of the Republic of Kosovo in 2008) and effective concrete results expressed in the reports of international monitoring institutions (WB, UNDP. UN, IMF, OECD, EC, Freedom House, etc.), the opinions of citizens from many self assessments of political institutions, media, civil society, as well as monitoring, analysis of my estimates, we can conclude that the Kosovo government and institutions during this period took these effective governing features:

- The governance through independent institutions, legitimate and functional according to legal provisions has begun. There are visible and concrete results, but it was not the right quality of leadership and officials in representative institutions such as the executive, judicial, administrative, public service or other independent institutions. There is special warning regarding the prosecution and the judiciary institutions, which were not effective against negative phenomena in institutions, and had no serious support from the main political 
institutions.

- There are no clear economic development policies. There has been a delay in creating suitable conditions for the businesses. There is a lack of reforms and clear economic and macroeconomic policies. Economic policies so far are not concrete and specific; they are not mid-term and long-term project and strategies for sustainable economic development.

- The authority and legitimacy of institutional governance is perceived negatively by citizens as a result of negative phenomena of certain groups in the party leadership and institutions.

- Competition between parties is unprincipled: followed by accusations, slander and insults and not enough coordination in positive decision-making.

- There is a lack of genuine opposition forces. As a result, there is low participation in elections and lack of qualitative and quantitative participation of citizens in the political process.

- Impunity by the courts of holders of negative phenomena in institutions and the interference of politics in law.

- Failure to punish subjects and their leaders by citizens through their vote as a result of emotional voters with a charged political awareness of the past and not enough cognitive, as well as the high concentration of power over public resources and the not sufficiently independent media.

- Serious violations of democratic principles in the electoral process which are affecting in the decrease of legitimacy, authority and effectiveness of government and instutions.

- The proportional electoral system influenced somewhat the coordination, cooperation and inter-party tolerance and reduced tension between them in the governing process and institutional functions. As a result of electoral proportionality, we are not faced with two tyraning majorities, but with some medium level parties forced into alliances and cooperation in order to create a position and opposition.

- There were and continue to be significant mediating interference from external factors in instiucionale crisis resolution and decision-making processes.

- Ethnical tolerance is increasing.

- Efforts to eliminate opposing political figures through undemocratic methods, unconstitutional and illegal, are fading. Tyrany as a method of political activity is decreasing.

- Rational civic courage and political activity has begun to increase. The civil society through NGOs is continuously consolidating. The media have also raised the level of independence, analysis and criticism. But the latter still show bias toward partisanship.

- Stratification and pluralistic structure of Kosovar society is missing, as a result of economic underdevelopment in manufacturing and service providing private spheres.

- Protection from external attacks is being carried out by international military forces and the accompanying policies of the International Community. The defence and surveillance of the border as well as the internal security are done by Kosovo police. Kosovo still lacks the military with its roles and functions.

- Law enforcement is not at the right level, but everyone is becoming aware about the situation and consequences. There are concrete efforts and demands, pressures and support from abroad to improve this essential area for democratic governance, without which there are no democratic government functions and effects in any sphere.

- Self-protection is done by the internal security institutions, supervised and controlled by institutional civil forces and the justice system.

- Cultural support and consolidation of democratic values in governance, economy, in respecting human and minority rights, gender equality etc. are growing.

- Interpretation and protection of the constitutionality and legality of the governance is being done by the constitutional court, which also includes international representatives.

\section{References}

Armitage, J. (2012). Gjyqësori dhe korrupsioni pengojnë ekonominë, Kosova sot, p.6.

Barometri Global i Korrupsionit (2013). Gjyqësia, sektori më i korruptuar, Kosova sot.

Constitution of the Repubilc of Kosovo 2008 ( with amendments I-XXIII ) retreieved from http://www.gjk-ks.org/repository/docs /Kushtetuta_RK_ang.pdf

European Commission, (2011), "Kosovo 2011 Progress Report", Brussels.

European Commission, (2012), "Kosovo 2012 Progress Report", Brussels.

European Commission, (2013), "Kosovo 2013 Progress Report", Brussels.

Declaration of Independence (17 February 2008). Retreived from http://www.assembly-kosova.org/?cid=2,128,1635 
Instituti Demokratik i Kosovës (KDI) (2013). Raport monitorues: Mbi 10 vjet parlamentarizem në Kosovë, Koha ditore 04.08.13, p. 2.

Inglehart, Wellzel, Christian (2005). Modernization, Cultural Change and Democracy: The Human Development Sequence, Cambridge, p.300.

Rambouillet Conference in (1999). Retreived from http://www.wsws.org/en/articles/1999/02/kos-f26.html

European Commission, Brussels (10 October 2012). Feasibility Study for a Stabilisation and Association Agreement between the European Union and Kosovo retrieved from http://ec.europa.eu/enlargement/pdf/key_documents/2012/package /ks_feasibility_2012_en.pdf

Fule, S. (2012). MSA për Kosovën, Gazeta Koha Ditore, p. 2.

Khaldun, S. ( 2012). Korrupsioni-problem i institucioneve dhe i shoqërisë, Koha ditore, p. 2.

Grupi i Kontaktit (2005). Nju Jork: Gjashtë parimet mbi zgjidhjen e problemit të Kosovës: retrieved from http://www.bing.com/search?q=Grupi+i+kontaktit+gjasht\%C3\%AB+parimet+e+zgjidhjes+se+problemit+t\%C3\%kosoves

Grupi Nndërkombëtar Drejtues (2012). Përfundimi i mbikëqyrjes ndërkombëtare të pavarësisë Kosova sot, p.1

International Court of Justice advisory opinion on Kosovo's declaration of independence retrieved from http://en.wikipedia.org/wiki/International_Court_of_Justice_advisory_opinion_on_Kosovo\%27s_declaration_of_independence

Merkel, W. (2010). Systemt ransformation. Eine Einfuhrung in die Theorie und Empirie der, Wiesbqden, p.30.

Sterio, M. (2009). The Kosovar Declaration of Independence: "Botching the Balkans" or Respecting International Law. Georgia Journal of International \& Comparative Law 267.

Fondi Monetar Ndërkombëtar (2013). Rritja ekonomike 2012, Bruksel, Telegrafi, p.1.

Organizata Europiane e Gjyqësisë (2013). Korrupsioni largon investitoret nga Kosova, Gazeta Kosova sot, p. 1.

Lipset, S. M. (1959). Economic development and political Legitimacy, in: APSR 53, 69-105

Lipset, S. M. (1960). Politikal man, London, p. 48.

Sekretari i përgjithshem i OKB-së (2012). Raporti tre mujor për Kosovën, Kosova Sot, p. 1.

Fule, S. (2012). MSA për Kosovën. Gazeta Koha Ditore, p. 2.

Vanhanen, T. (2003). Demokratization. A Comparative Analysis of 170 Countries, London.

United Nations, Resolution 1244, adopted by the Security Council, 4011th meeting. Retreived from https://www.essex.ac.uk/armedcon/story_id/000367.pdf

Galluci, G., M. (2011). The Ahtisaari Plan and North Kosovo. Retrieved from http://www.transconflict.com/10/wpcontent/uploads/2011/11/PolicyPaper_AhtisaariPlanNorthKosovo.pdf

Freedom House, 2010, 2011, 2012, Parts of Kosovo. Retrieved from http://www.freedomhoese.org/ on December $28^{\text {th }}, 2012$.

GJND (2010). Opinioni për Deklaratën e Pavarësisë 2009. Gazeta Koha Ditore.

Kosovo Declares Independence from Serbia. MSNBC. Retrieved from http://www.msnbc.msn.com/id/23203607. February $18^{\text {th }}, 2008$.

Letter dated 26 March 2007 from the Secretary-General addressed to the President of the Security Council retrieved from http://www.unosek.org/docref/Comprehensive_proposal-english.pdf

UNDP (United Nations Development Programme), (2009). Human Development Report 2009.

UNDP (United Nations Development Programme), (2012). Overcoming barriers: Human mobility and development

UNDP (2010). Kosovo Human Development Report 2011: Social Inclusion.

Banka Qendrore të Kosovës (2012). Gjendja financiare, Gazeta Kosova Sot, p. 20.

BQK (2011). Raporti vjetor 201.

BQK. Raporti i Stabilitetit Financiar nr 3. Retrieved from http://www.bqk-kos.org/?cid=1,131

BQK. Raporti i Bilancit të Pagesave. Retrieved from http://www.bqk-kos.org/?cid=1,133

Fukuyama, F. (2010). State Building-Governance and World Order in the Twenty-First Century in Albanian, AllS, Tiranë, p. 174-177.

Rohan, A. (2012). Plani i Ahtisarit permbanë autonominë e serbëve. Interview. 